\title{
The Combined Effect of Extract Seaweed and DHP on Placental Malaria
}

\author{
Zainabur Rahmah ${ }^{1, *}$, Nurfianti Indriana ${ }^{2}$, Lina Fitria Astari ${ }^{3}$, Alvi Milliana $^{4}$, Sutikno $^{5}$ \\ ${ }^{I}$ Departement of Parasitology, Faculty of Medicine and Health Sciences, UIN Maulana Malik Ibrahim Malang, \\ Indonesia \\ ${ }^{2}$ Department of Obstetrics Gynecology, Faculty of Medicine and Health Sciences, UIN Maulana Malik Ibrahim Malang, \\ Indonesia \\ ${ }^{3}$ Department of Pediatrics, Faculty of Medicine and Health Sciences, UIN Maulana Malik Ibrahim Malang, Indonesia \\ ${ }^{4}$ Department of Microbiology, Faculty of Medicine and Health Sciences, UIN Maulana Malik Ibrahim Malang, \\ Indonesia \\ ${ }^{5}$ Faculty of Economics, UIN Maulana Malik Ibrahim Malang, Indonesia \\ *Corresponding author. Email: zainabur.rahmah@kedokteran.uin-malang.ac.id
}

\begin{abstract}
Placental malaria is characterized by infected erythrocyte cytoadherence and TNF- $\alpha$ expression in the intervillous placental space. This can interfere with the transport of nutrients, which can affect the growth of the fetus. Seaweed (Eucheuma cottonii) is a typical Indonesian plant containing polysaccharide sulfate that has antimalarial function. The purpose of this study was to investigate the effect of seaweed (Eucheuma cottonii) combined with DHP in the degree of parasitemia, cytoadherence, TNF- $\alpha$, and fetal growth of mice in Plasmodium berghei infection. Mice pregnant 24 days on day 9 post-mating in Plasmodium berghei infection then divided into 4 groups: group A (without treatment), group B (DHP 0,0364 mg / gr BB), group C (seaweed 0,5 mg / grBB), group D (DHP 0,0364 mg / gr BB and seaweed $1 \mathrm{mg} / \mathrm{grBB})$. Analysis using Structural Equation Modeling ( $\mathrm{SEM}$ ) ( $\mathrm{t}_{\mathrm{table}} \geq 1.96$ ) showed the Group (A), causing a high degree of parasitemia, TNF- $\alpha$ expression, cytoadherence, and low birth weight. Group (B), decreased degree of parasitemia, but cytoadherence, TNF- $\alpha$ expression, and low birth weight remained high. Group (C), decreased degree of parasitemia, cytoadherence, TNF- $\alpha$ expression and prevent low birth weight. Group (D), decreased degree of parasitemia, cytoadherence, TNF- $\alpha$ expression and prevent low birth weight. Eucheuma cottonii single therapy and combination therapy Eucheuma cottonii with DHP can prevent parasitemia, cytoadherence, TNF- $\alpha$, and low birth weight while single DHP therapy may decrease the degree of cytoadherence parasitemia but cytoadherence, TNF- $\alpha$ expression, and low birth weight but high.
\end{abstract}

Keywords: Parasitemia, cytoadherence, Low birth weight, Eucheuma cottonii, Dinydroartemisinin

\section{INTRODUCTION}

Malaria infection during pregnancy is a very serious problem with pregnant women, fetuses, and newborn children [1]. Infected pregnant women will be replaced that will require nutrition from mother to fetus. This causes intrauterine growth retardation [2]. Placental malaria is characterized by the infiltration of inflammatory cells and increased proinflammatory cytokines in the intervillous region [3]. Increased proinflammatory cytokines such as $\mathrm{TNF}-\alpha$ produced by macrophages/ monocytes help clear the placenta from malaria parasites through the activity of fogositosis [4].
Proinflammatory cytokine responses such as TNF- $\alpha$ are stronger during placental malaria affecting the fetus as in the first trimester of spontaneous abortion, by necrosis due to implantation of the fetus. In addition, there is also IFN- $\gamma$. [5][6]. Tumour necrosis factor- $\alpha$ will also stimulate the cytoadherence of parasitic erythrocytes in placental capillaries by increasing the ligand bonds of Plasmodium falciparum Erythrocyte Protein-1 membranes (PfMP-1) bind to CSA receptors that will cause impaired blood flow in the placenta and ultimately fetal malformations. When the process that occurs in second trimester pregnancy occurs restriction of infant growth, who have low birth weight. In addition, increased 
prostaglandin synthesis, along with elevated TNF- $\alpha$ concentrations in the placenta and also acute parasitemia, may lead to preterm pregnancy [7][8].

In this study DHP in combination with Eucheuma cattoni. Dihydroartemisinin Piperaquine (DHP) contains artemisinin (ART) and chloroquine. Artemisinin is a substance produced by the Artemisia annua plant that has been used for a long time as a malaria drug [9]. Artemisinin and chloroquine belong to the class of antimalarial drugs of the penacillary sesquiter group and are one of the drugs of choice in malaria therapy because they have advantages that are easily absorbed, safe, and quickly converted into active metabolite forms. [10].

Eucheuma cattoni seaweed is a plant that is easy to find in Indonesia, especially on the coast of Madura. Eucheuma cottonii is a multicellular red algae (multicellular) and is one of Carragaenaphyces, the carnage-producing seaweed. Carrageen content in each species of Eucheuma cattoni ranges from $54 \%-73 \%$ depending on the type and location. In Indonesia, the level of carrageen seaweed type Eucheuma ranged between $61.5 \%-67.5 \%$ [11]

Carrageenans are linear or straight polysaccharide sulfates and are galactan molecules, with the major units being galactose. Carrageen is a seaweed sap extracted with water or an alkaline solution of certain species of the Rhodophyceae class (red algae). Carrageen is a hydrocolloid compound comprising potassium, sodium, magnesium, and potassium ester calcium sulfate. Carrageenan is a large molecule consisting of over 1,000 galactose residue. Therefore, Carrageenan is divided up the three main groups are kappa, iota, and lambda carrageen clear structure. Carrageenan can be obtained from red algae; one of its kind is from the Euchema sp group [12].

Research conducted [13], which is done in vitro, states that polysaccharide sulfate contained in seaweed Euchema sp serves as antimalarial and can inhibit Plasmodium to invade the red blood cells. So in this study will examine the DHP combined with seaweed Eucheuma cattoni inhibiting the occurrence of cytoadherence, TNF- $\alpha$, and low birth weight in Balb / C mice infected with Plasmodium berghei parasite.

\section{MATERIALS AND METHODS}

\subsection{Research design and samples}

In vivo, experimental laboratory study was conducted using Balb / C female mice weighing 20-30 grams, aged 13-15 weeks and healthy. After synchronization of the estrous cycle, the samples were then paired with single male rats simultaneously mated in one night [14], and then divided into four groups, group A (Plasmodium berghei infection without therapy), group B (Plasmodium berghei infection in treatment with DHP dose $0,0364 \mathrm{mg} / \mathrm{gr} \mathrm{BB}$ ), group $\mathrm{C}$ (Plasmodium berghei infection treated with seaweed $0.5 \mathrm{mg} / \mathrm{gr} \mathrm{BB})$, group D (Plasmodium berghei infection in DHP therapy 0.0364 $\mathrm{mg} / \mathrm{gr}$ BB and seaweed $1 \mathrm{mg} / \mathrm{gr} \mathrm{BB}$ ). Twenty-four mice were divided into 4 groups (each group of 6 mice) in Plasmodium berghei infection intraperitoneally on day 9 of post-marriage. The Plasmodium berghei ANKA strain used as an inoculant in this study was obtained from the Parasitology Laboratory of Faculty of Medicine Universitas Brawijaya Malang. The mice are weighed daily and on the parasite check, and killed on the $18^{\text {th }}$ day after the wedding. Low birth weight (BBLR) was detected by weighing all fetuses using Mettler AE 50 analytical, cytoadherence in detection with HE, TNF- $\alpha$ in detection with immunohistochemical staining, and parasitemia in detection with negrosin eosin staining. This research has been approved by Health Research Ethics Committee, Faculty of Medicine and health sciences Universitas Islam Negeri Maulana Malik Ibrahim Malang (No.009 / EC / KEPK-FKIK / 2018), and this research is done at Parasitology Laboratory of Faculty of Medicine UIN Maulana Malik Ibrahim Malang and Parasitology Laboratory of Faculty of Medicine Universitas Brawijaya.

\subsection{The principles of oestrus synchronization}

Oestrus synchronization was done by utilizing the natural phenomenons, namely Lee-Boot effect, Pheromone effect, and Whiten effect [15][16].

\subsection{Isolation of placenta and fetus}

Isolation of placenta and fetus was done on the $18^{\text {th }}$ day post-mating. The suspected pregnant mice (physically) were scarified under anesthesia with chloroform, and surgery was performed by opening the abdominal wall to take the uterus. The fetus was weighed individually, and the placentas were divided into two parts; a part isolated then stored in $-80^{\circ} \mathrm{C}$ for analysis of placental cytokines and the other part fixed with $10 \%$ formaldehyde for histopathological studies after $\mathrm{HE}$ staining.

\subsection{Examination of a degree of parasitemia and therapy with a combination of seaweed (Eucheuma Cottonii) with Dihydroartemisinin Piperaquine (DHP)}

Inoculation was performed by intraperitoneal injection of $1 \times 10^{6}$ Plasmodium berghei ANKA strain (first passage) per $\mathrm{mL}$ of blood on a ninth day after the mating. To observe the degree of parasitemia, $10 \mathrm{~mL}$ of blood was isolated from the tail of the mice and dropped onto the sliding glass. The droplets are applied as a thin smudge and dried. Then the slides are fused with absolute methanol until evenly distributed and dried. The slides are stained with Giemsa solution (a mixture of Giemsa stain (Merck, HX612241) and Giemsa buffer (Bioanalitika, Indonesia) at a ratio of 1: 9 for 30 minutes, 
rinsed with water and dried.If degree of parasitemia is $2 \%$, then in therapy with a combination of grass (Eucheuma Cottonii) Dihydroartemisinin Piperaquine (DHP) for 7 days, Paracitemia degree was determined by examining a blood smear under a microscope with 1000 $\times$ magnification Percentage of parasitemia calculated based on erythrocyte numbers infected with malaria parasites per 1000 erythrocytes Assessment of blood smear to measure degree parasitemia is performed daily from day 10 to day 18 .

\subsection{Examination and measurement of cytoadherence}

Examination of cytoadherence was performed on the histopathological slides stained with $\mathrm{H}-\mathrm{E}$ at the Laboratory of Pathological Anatomy dr. Sutomo Hospital, Faculty of Medicine, Universitas Airlangga Surabaya, Indonesia. The slides of placental tissue that had been stained with $\mathrm{H}-\mathrm{E}$ were then examined by 2 independent examiners using a light microscope under $1,000 \times$ magnifications. The levels of cytoadherence were determined by counting the number of parasitized red blood cells (RBCs) among 1,000 RBCs in the intervillous space of placenta by using two hand counters.

\subsection{TNF- $\alpha$ examination in Placenta}

TNF- $\alpha$ expression was measured by immunohistochemistry with $\mathrm{TNF}-\alpha$ monoclonal $\mathrm{Ab}$ (Santa Cruz, sc-5235 TNF- $\alpha$ ). After all the slides were observed, the average number of TNF- $\alpha$ expressions in each group was calculated. The slide is observed under microscopic with $1000 \mathrm{x}$ magnification using emersion oil. Each slide is observed below 20 fields of view and records the number of expressed TNF- $\alpha$. TNF- $\alpha$ expression was detected as a brown color in the cell nucleus and cytoplasmic area.

\subsection{Data analysis}

The data were analyzed using the Structural Equation Modeling (SEM) method with a true tool of Smart Partial Least Square (PLS) software. The purpose of this analysis was to build and test the statistical model in the form of causal models

\section{RESULTS}

The number of degree of parasitemia was calculated under light microscopy using $1000 \mathrm{x}$ magnification, as shown in Figure 1. The number of cytoadherence was calculated under light microscopy using $1000 \mathrm{x}$ magnification, depicted in Figure 2.

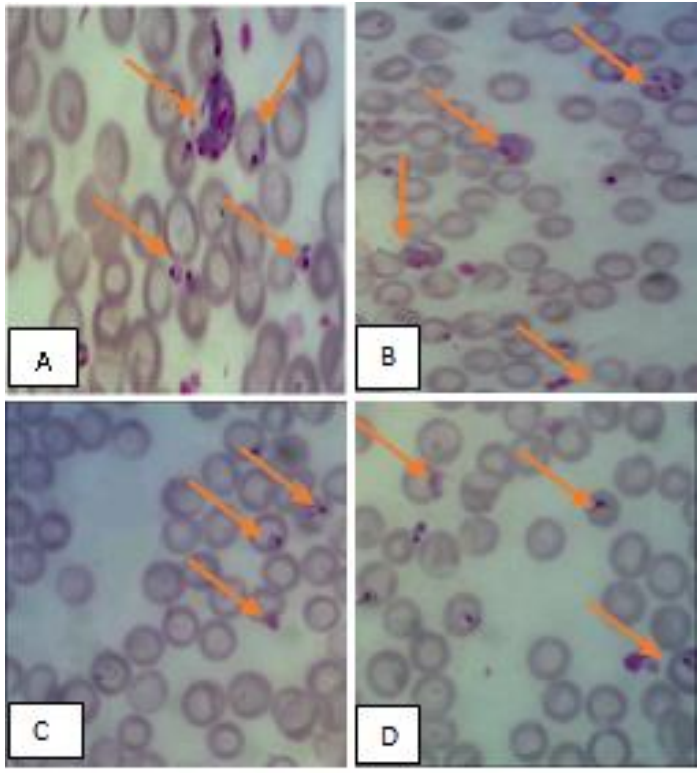

Figure 1 The erythrocytes infected with Plasmodium berghei ANKA strain. Arrows indicate infected erythrocytes on day 18 postmating or day 9 post-infection of Plasmodium berghei infected pregnant mice. (A) (without treatment). (B) (treatment DHP 0,0364 mg/gr $\mathrm{BB})$. (C) (seaweed 0,5 mg / grBB). (D) (treatment DHP $0,0364 \mathrm{mg} / \mathrm{grBB}$ and seaweed $1 \mathrm{mg} / \mathrm{grBB}$ ).

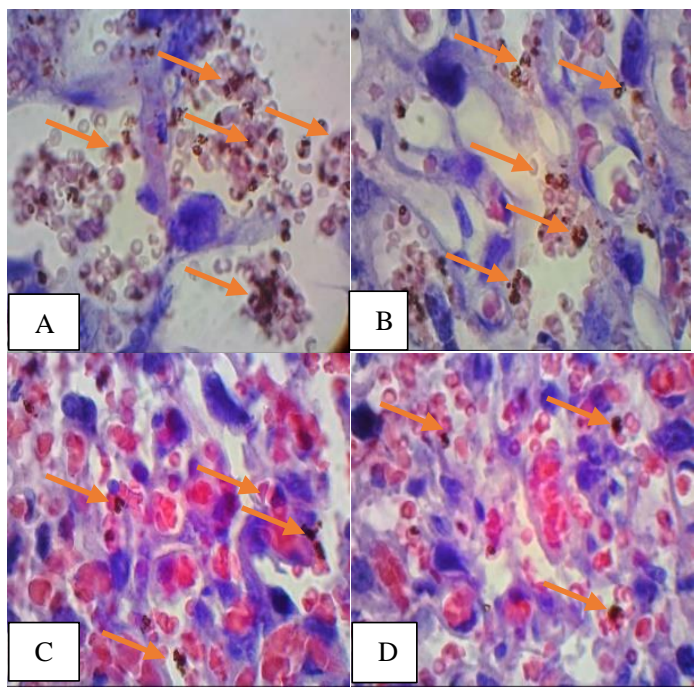

Figure 2 Cytoadherence of Plasmodium berghei infected erythrocytes in the placenta. A) (without treatment). (B) (treatment DHP 0,0364 mg/gr BB). (C) (treatment seaweed 0,5 mg / grBB). (D) (treatment DHP 0,0364 $\mathrm{mg} / \mathrm{grBB}$ and seaweed $1 \mathrm{mg} / \mathrm{grBB}$ ). Arrows indicate infected erythrocytes undergoing sequestration in the placental intervillous space (examined by Olympus Microscope under 1,000 $\times$ magnification). 


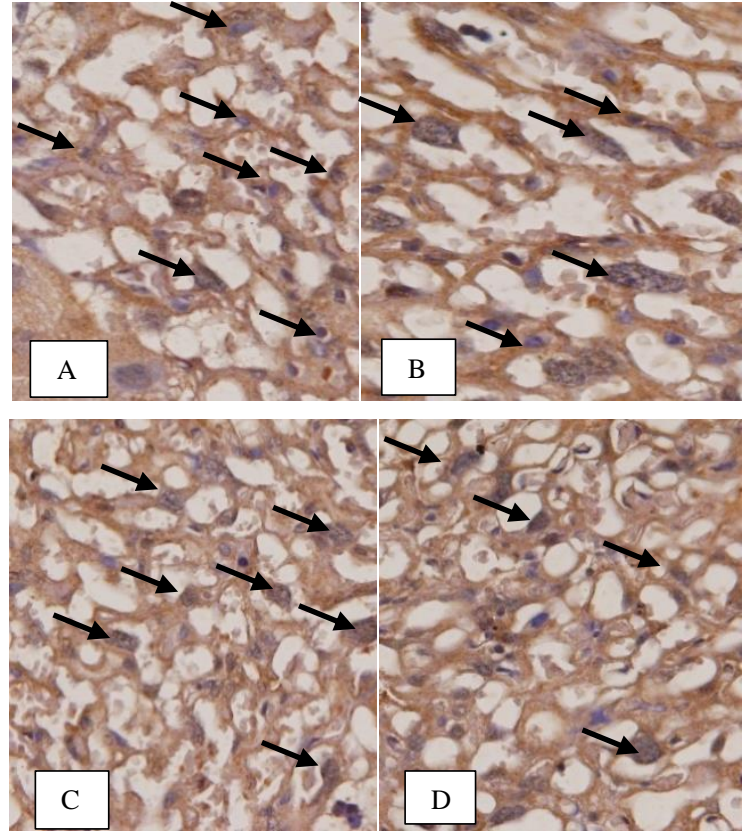

Figure 3 TNF- $\alpha$ expression by immunohistochemistry staining. (without treatment). (B) (treatment DHP 0,0364 $\mathrm{mg} / \mathrm{gr} \mathrm{BB}$ ). (C) (treatment seaweed $0,5 \mathrm{mg} / \mathrm{grBB}$ ). (D) (treatment DHP $0,0364 \mathrm{mg} / \mathrm{grBB}$ and seaweed 1 $\mathrm{mg} / \mathrm{grBB})$. Black arrows indicate TNF- $\alpha$ expression.

The number of TNF- $\alpha$ expressions was calculated under light microscopy using $1000 \mathrm{x}$ magnification, as shown in Figure 3. Data analysis and calculation were done by using the Non-Parametric Structural Equation Modeling, and the result can be seen in Figure 4.

This study establishes a 95\% confidence interval or $\mathrm{p}$ $=0.05$, which means significant results are obtained when the calculated value $t \geq 1,96$. Statistical analysis showed that Group A was infected with malaria ( $\mathrm{t}_{\text {count }}=$ $1.98 \geq t_{\text {table }}=1.96$ ) in this group not treated, causing a high degree of parasitemia $\left(t_{\text {count }}=1.13 \geq t_{\text {table }}=1.96\right)$, high

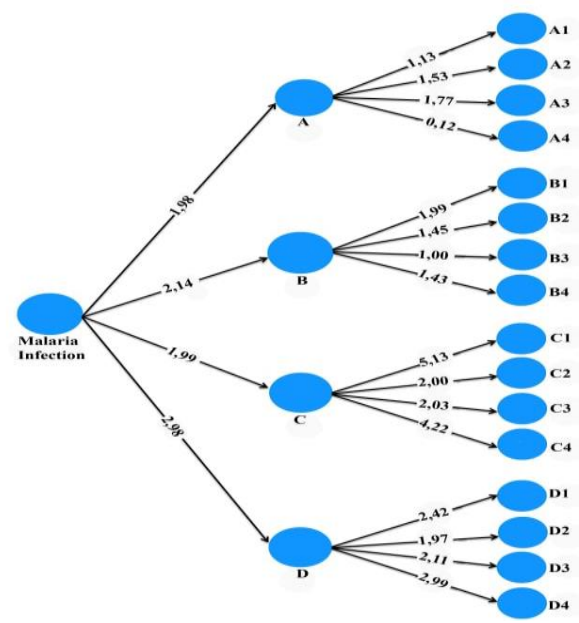

Figure 4 Structural Equation Modeling (SEM) for determining the relationship among degree parasitemia, cytoadherence, expression TNF- $\alpha$, and low birth weight. cyoadherence $\left(\mathrm{t}_{\text {count }}=1,53 \geq \mathrm{tt}_{\mathrm{able}}=1.96\right)$, high expression TNF- $\alpha\left(t_{\text {count }}=1.77 \geq t_{\text {table }}=1.96\right)$ also caused low birth weight $\left(t_{\text {count }}=0.12 \geq t_{\text {table }}=1.96\right)$. In group $A$ the high degree of parasitemia caused cytoadherence in the placenta $\left(\mathrm{t}_{\text {table }}=0.01\right)$ high expression of TNF- $\alpha$ in placenta $\left(t_{\text {table }}=1.26\right)$ and low birth weight $\left.t_{\text {table }}=1.60\right)$. Statistical analysis showed that Group B infected with malaria $\left(t_{\text {count }}=2.14 \geq t_{\text {table }}=1.96\right)$ in this group in DHP therapy led to decreased degree of parasitemia $\left(\mathrm{t}_{\text {count }}=1.99 \geq \mathrm{t}_{\text {table }}=1.96\right)$, but cyoadherence in placenta was high $\left(t_{\text {count }}=1.45 \geq t_{\text {table }}=1.96\right)$, high expression of TNF- $\alpha$ in placenta $\left(t_{\text {count }}=1.00 \geq t_{\text {table }}=1.96\right)$ also causes low birth weight $\left(\mathrm{t}_{\text {count }}=1.43 \geq \mathrm{t}_{\text {table }}=1,96\right)$. In group $\mathrm{B}$, parasitemia decreased, causing decreased cytoadherence in the placenta $\left(t_{\text {table }}=1.96\right)$, decreased cytoadrence caused decreased expression of TNF- $\alpha$ in placenta ( $t_{\text {table }}$ $=1.99$ ) but low birth weight $t_{\text {table }}=1.60$ ). Group $\mathrm{C}$ infected with malaria $\left(\mathrm{t}_{\text {count }}=1.99 \geq \mathrm{t}_{\text {table }}=1.96\right)$ in this group in therapy with (treatment seaweed $0.5 \mathrm{mg} / \mathrm{grBB}$ ) caused decreased degree of parasitemia $\left(\mathrm{t}_{\text {count }}=5.13 \geq \mathrm{t}_{\text {table }}=1.96\right)$, decreased expression of TNF- $\alpha$ $\left(\mathrm{t}_{\text {count }}=2.03 \geq \mathrm{t}_{\text {table }}=1.96\right)$ and prevented the occurrence of low birth weight $\left(\mathrm{t}_{\text {count }}=4.22 \geq \mathrm{t}_{\text {table }}=1.96\right)$. In group $\mathrm{C}$ the decreased degree of parasitemia causes decreased cytoadherence in the placenta $\left(t_{\text {table }}=3.72\right)$ decreased expression of TNF- $\alpha\left(t_{\text {table }}=3.16\right)$ and prevented low birth weight $\left(\mathrm{t}_{\mathrm{table}}=4.22\right)$. Group $\mathrm{D}$ was infected with malaria $\left(\mathrm{t}_{\text {count }}=2.98 \geq \mathrm{t}_{\text {table }}=1.96\right)$ in this group in therapy with (DHP treatment $0.0364 \mathrm{mg} / \mathrm{grBB}$ and seaweed 1 $\mathrm{mg} / \mathrm{grBB}$ ) causing decreased degree of parasitemia $\left(t_{\text {count }}=2.42 \geq t_{\text {table }}=1.96\right)$, decreased cyoadherence in placenta $\left(t_{\text {count }}=1.97 \geq t_{\text {table }}=1.96\right)$, decreased TNF- $\alpha$ expression in placenta $\left(t_{\text {count }}=2.11 \geq t_{\text {table }}=1.96\right)$ and no low birth weight $\left(t_{\text {count }}=2.99 \geq t_{\text {table }}=1.96\right)$. In group $D$ the decreased degree of parasitemia causes decreased cytoadherence in the placenta $\left(t_{\text {table }}=2.20\right)$, decreased expression of TNF- $\alpha\left(\mathrm{t}_{\text {table }}=1.98\right)$ and no low birth weight $\mathrm{t}_{\text {table }}=3.60$ ).

A model hypothesis of the relationship among degree parasitemia, cytoadherence, expression TNF- $\alpha$, and low birth weight of mice placental malaria is shown in Figure 5 . This study set a confidence interval of $95 \%$ or $p=0.05$, which means the result is from the count value of $t \geq 1.96$. Statistical analysis showed that Group A was infected with malaria $\left(\mathrm{t}_{\text {count }}=1.98 \geq \mathrm{t}_{\text {table }}=1.96\right.$; path coefficients $=0.965 ; \mathrm{R} 2=0.932$ ) in this group not treated causing high degree of parasitemia $\left(\mathrm{t}_{\text {count }}=1.13 \geq \mathrm{t}_{\text {table }}=1,96\right.$ coefficients path $=0.714)$, high cyoadherence $\left(\mathrm{t}_{\text {count }}=1.53 \geq \mathrm{t}_{\text {table }}=\right.$ 1,96; path coefficients $=0.850)$, high expression TNF- $\alpha$ $\left(\mathrm{t}_{\text {count }}=1.77 \geq \mathrm{t}_{\text {table }}=1.96\right.$; path coefficients $\left.=0.905\right)$ also results in low birth weight $\left(\mathrm{t}_{\text {count }}=0.12 \geq \mathrm{t}_{\text {table }}=1.96\right.$; path coefficients $=0.832$ ). In group $\mathrm{A}$ the high degree of parasitemia causes cytoadherence in the placenta $\left(\mathrm{t}_{\mathrm{table}}=\right.$ 0.01 ; path coefficients $=0.466$ ) high expression of TNF$\alpha$ in the placenta $\left(t_{\text {table }}=1.26\right.$; path coefficients $\left.=0.297\right)$ and low birth weight $\mathrm{t}_{\text {table }}=1,60$; path coefficients = 0.832 ). 


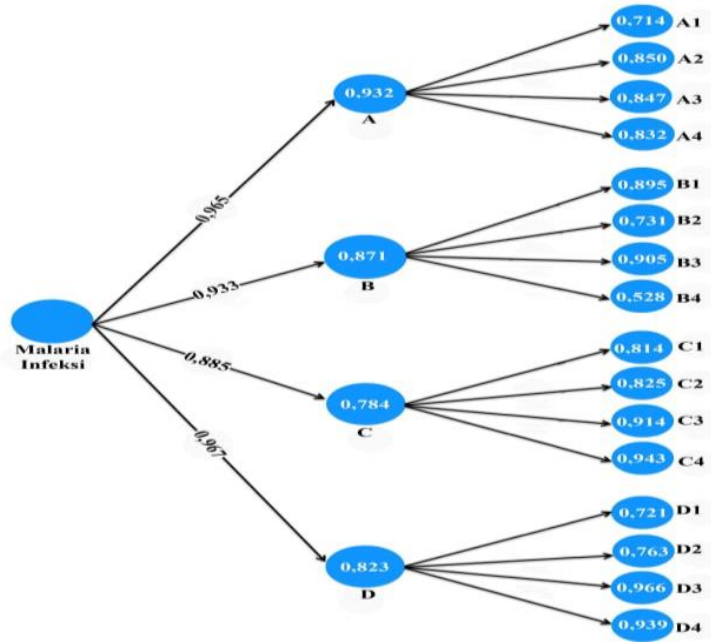

Figure 5 Model hypothesis of the relationship among expression degree parasitemia, cytoadherence, expression TNF- $\alpha$, and low birth weight in mice placental malaria illustrated by Value Path Coefficients and $\mathrm{R}^{2}$.

Statistical analysis showed that group B was infected with malaria $\left(\mathrm{t}_{\text {count }}=2.14 \geq \mathrm{t}_{\text {table }}=1.96\right.$; path coefficients $=$ $0.933 ; \mathrm{R} 2=0.871$ ) in this group in DHP therapy resulting in decreased degree of parasitemia $\left(\mathrm{t}_{\text {count }}=1.99 \geq \mathrm{t}_{\text {table }}=\right.$ 1 , 96; path coefficients $=0.895)$, but high cyoadherence in placenta $\left(t_{\text {count }}=1,45 \geq t_{\text {table }}=1,96\right.$; path coefficients $=$ $0,895)$, high expression of TNF- $\alpha$ in placenta $\left(t_{\text {count }}=\right.$ $1.00 \geq \mathrm{t}_{\text {table }}=1,96$; path coefficients $\left.=0.905\right)$ also causes low birth weight $\left(\mathrm{t}_{\text {count }}=1.43 \geq \mathrm{t}_{\text {table }}=1.96\right.$; path coefficients $=0.943$ ). In group B, parasitemia decreased, causing decreased cytoadherence in the placenta $\left(\mathrm{t}_{\mathrm{table}}=\right.$ 1.96), decreased cytoadrence caused decreased expression of TNF- $\alpha$ in placenta $\left(t_{\text {table }}=1.99\right)$ but low birth weight $t_{\text {table }}=1.60$ ). Group $C$ was infected with malaria $\left(t_{\text {count }}=1.99 \geq t_{\text {table }}=1.96\right.$; path coefficients $=$ $0.885 ; \mathrm{R} 2=0.784)$ in this group in therapy with (treatment seaweed $0.5 \mathrm{mg} / \mathrm{grBB}$ ) causing decreased degree of parasitemia $\left(\mathrm{t}_{\text {count }}=5,13 \geq \mathrm{t}_{\text {table }}=1,96\right.$; path coefficients $=0.814)$, decreased cyoadherence $\left(\mathrm{t}_{\text {count }}=\right.$ $2.00 \geq \mathrm{t}_{\text {table }}=1.96$; path coefficients $\left.=0.825\right)$, decreased expression TNF- $\alpha\left(\mathrm{t}_{\text {count }}=2.03 \geq \mathrm{t}_{\text {table }}=1.96\right.$; path coefficients $=0.914$ ) and prevents the occurrence of low birth weight $\left(\mathrm{t}_{\text {count }}=4.22 \geq \mathrm{t}_{\text {table }}=1.96\right.$; path coefficients $=0.943$ ). In group $C$ the decreased degree of parasitemia causes decreased cytoadherence in the placenta $\left(\mathrm{t}_{\text {table }}=\right.$ 4.20; path coefficients $=0.386$ ) decreased expression of TNF- $\alpha\left(\mathrm{t}_{\text {table }}=3,16\right.$; path coefficients $\left.=0.248\right)$ and prevented the occurrence of low birth weight $\mathrm{t}_{\text {table }}=3$, 72 ; path coefficients $=0,096$ ). Group $\mathrm{D}$ was infected with malaria $\left(\mathrm{t}_{\text {count }}=2.98 \geq \mathrm{t}_{\text {table }}=1.96\right.$; path coefficients $=$ 0.907; R2 $=0.823$ ) in this group in therapy with (DHP treatment $0.0364 \mathrm{mg} / \mathrm{grBB}$ and seaweed $1 \mathrm{mg} / \mathrm{grBB}$ ) degree of parasitemia $\left(t_{\text {count }}=2,42 \geq t_{\text {table }}=1,96\right.$; path coefficients path coefficients $=0,721)$, decrease of cyoadherence in placenta $\left(t_{\text {count }}=1,97 \geq t_{\text {table }}=1,96\right.$; path coefficients $=0,763)$, decrease expression TNF- $\alpha$ in placenta $\left(\mathrm{t}_{\text {count }}=2.11 \geq \mathrm{t}_{\text {table }}=1.96\right.$; path coefficients $=$ $0.966)$ and no low birth weight $\left(t_{\text {coun }} t=2,99 \geq t_{\text {table }}=1,96\right.$; path coefficients $=0.934)$. In group $\mathrm{D}$ the decreased degree of parasitemia causes decreased cytoadherence in the placenta $\left(t_{\text {table }}=2.20\right.$; path coefficients $\left.=0.215\right)$, decreased expression of TNF- $\alpha\left(t_{\text {table }}=0.165\right)$ and no low birth weight $t_{\text {table }}=3.60$; path coefficients $=0.215$ ).

\section{DISCUSSION}

The first findings of this study indicate that there is a high degree of parasitemia, cytoadherence, and TNF $\alpha$ expression in the intervillous placenta in malaria-infected mice in the untreated group. Cytoadherence occurs as a result of molecular interaction of the Plasmodium falciparum Erythrocyte Membrane Protein-1 (PfEMP-1) ligand with a receptor containing in placenta. The DBL$3 \gamma$ area of PfEMP-1 is encoded by var1CSA, and the DBL2 $\gamma$ region of PfEMP-1 is encoded by var2CSA, which is a parasite conducting cytoadherence with Chondroitin Sulfate A (CSA) in the placenta [17]. Placental malaria also causes an increase in local immune responses, especially cellular immune responses, through the accumulation of inflammatory cells in the placenta. In malaria-infected pregnancies, there is an increase in the production of proinflammatory cytokines such as TNF- $\alpha$ that are needed to clear parasites. However, high expression of TNF- $\alpha$ in the placenta is associated with intrauterine growth retardation [18].

In the DHP-treated study group, there was a decreased degree of parasitemia, but cytoadherence and TNF- $\alpha$ expression remained high. Dihydroartemisinin Piperaquine (DHP) contains Chloroquine and artemisinin. The mechanism of action of Chloroquine and artemisinin so that able decreases the degree of the parasite is related to decreasing the degree of the parasite through the ability to block the synthesis of parasite enzymes in the formation of DNA and RNA so that the cleavage process is disturbed, other than that Chloroquine binds to heme which will inhibit hemozoin formation. Hence, the heme accumulates in the form of free heme, which is toxic and leads to Plasmodium's death [19],[20],[21],[22],[23].

Artemisinin is known to have a molecular structure containing peroxide bridge, Artemisinin's working mechanism decreases the degree of the parasite is closely related to its molecular structure in which the digestion of hemoglobin is disconnected by $\mathrm{Fe} 2^{+}$ions into highly reactive free radicals. These Artemisinin radicals subsequently inhibit and modify the various molecules in Plasmodium that cause the Plasmodium to die [24],[25]. Other studies explain the mechanism of action of Artemisinin by inhibiting the enzyme of the malarial calcium-dependent ATP use (PfATP6) located in the membrane-bound intracellular compartment called the endoplasmic reticulum. In Plasmodium, this compartment is widespread in the cytoplasm outside the food vacuole. The resulting free radicals Artemisinin bind and inhibit PfATP6 irreversibly and specifically to cause parasite growth inhibited [26]. 
In the $\mathrm{C}$ and $\mathrm{D}$ group studies, there was a decreased degree of parasitemia, cytoadherence, TNF- $\alpha$ expression, and preventing low birth weight. The ability of the extract seaweed (Eucheuma Cottonii) and Dihydroartemisinin Piperaquine (DHP) is caused by seaweed Eucheuma cottonii containing polysaccharides [17]. Negatively charged polysaccharides such as heparin, chondroitin and dextran sulfate, fucoidan, and hyaluronic gondosaminoglycan (GAG) can prevent infected red cells cytoadherence into host receptors [27],[28]. Heparin polysaccharides also have antimalarial activity by inhibition of invasion of red blood cells at the merozoite stage [29],[30],[31].

\section{CONCLUSION}

The combination of Eucheuma cottonii with DHP prevents levels of parasitemia, cytoadherence, TNF- $\alpha$, and low birth weight, while single DHP therapy may decrease the degree of parasitemia cytoadherence and TNF expression but leads to low birth weight.

\section{ACKNOWLEDGMENT}

The research was conducted by the Ministry of Religious Affairs of the Republic of Indonesia and Faculty of Medicine and Health Sciences, Universitas Islam Negeri Maulana Malik Ibrahim Malang, Indonesia. We would like to thank Heni Endrawati, S.Si from Parasitology Laboratory Faculty of Medicine Universitas Brawijaya and Surya Kurnia Hayati, S.Si from Biomedical Laboratory of Faculty of Medicine Universitas Brawijaya for assistance in Immunohistochemical

\section{REFERENCES}

[1] World Health Organization (WHO), The Malaria Report (Online), 2017, http://www.who.int/malaria/wmr2017/malar2017

[2] A. Muthusamy, R.N. Achur, V.P., Bhavanandan, G.G. Fouda, D.W. Taylor, " Plasmodium falciparum Infected Erythrocytes Adhere Both in the Intervillous Space and on the Villous Surface of Human Placenta by Binding to the low-sulfated chondroitin sulfate proteoglycan receptor", Am J Pathol. 164 (2004) 2013-2025. DOI: https://doi.org/10.1016/S0002-9440(10)63761-3

[3] E.G. Kane, W. Andrew, Taylor-Robinson. "Prospects and Pitfalls of Pregnancy-Associated Malaria Vaccination Based on the Natural Immune Response to Plasmodium falciparum Var2CSAExpressing Parasites. Review Article". SaGeHindawi Acess to Research Malaria. (2010) 21. DOI: https://doi.org/10.4061/2011/764845

[5] J. Calleja-Agiu \& M.P. Brincat, Recurrent Miscarriages: What is the Role of Cytokines?
Gynecological Endocrinology, 2008, 24 (120): pp. 663-668.

[6] K.L. Silver, K. Zhong, R.G.F. Leke, D.W. Taylor, K.C. Kain, Dysregulation of Angiopoietins is Associated with Placental Malaria and Low Birth Weight, PLoS ONE, 5(3) (2010) pp.120-124, DOI: https://doi.org/10.1371/journal.pone.0009481

[7] L.J. Hoon, Artemisinin \& Its Derivatives For Antimalarial Agents, 2000, synmed.snu.ac,kr/courses/graduate/di.

[8] P.M. Newman, H. Wanzira, G. Tumwine, E. Arinaitwe, S. Waldman, J. Achan, D. Havlir, P.J. Rosenthal, G. Dorsey, T.D. Clark, D. Cohan, "Placental Malaria Among HIV-Infected and Uninfected Women Receiving Anti-Folates in a High Transmission Area of Uganda", Malaria Journal, 2009, 8:254, DOI:10.1186/1475-2875-8254.

[9] A.L. Suguitan, T.J. Cadigan, T.A. Nguyen, MalariaAssociated Cytokine Changes in the Placenta of Women with Pre-term Deliveries in Yaounde, Cameroon. Am J Trop Med Hyg, 69(6) (2003) 574581.

[10] P.F. Mens, E.C. Bojtor, D.F.H. Henk, "Schalling, Moleculer Interactions in The Placenta During Malaria Infection", European Journal af Obstetrics and Gynecology and Reproductive Biology, 15(2) (2010), pp. 126-132.

[11] S.R. Meshnick, "Artemisinin And The Anti Malarial Endoperoxides, From Herbal Remedy To Targeted Chemotherapy", Microbiology Review, 1996, 60, pp. 301-315.

[12] S. McKinnon, T. Durst, J.T. Arnaso, Angerhoferc J. Pezzuto, P.E. Sanchez - Vindas, "Antimalarial Activity Of Tropical Meliaceae Extract And Gedunin Derivates", Journal Natural Product, 1997, 60.

[13] Santi, Kandungan Gizi Rumput Laut. Yogyakarta 2010.

[14] J.J. Marques, E. Vilanova, P.A.S. Mourão, X. Fernàndez-Busquets, "Marine organism sulfated polysaccharides exhibiting signifcant antimalarial activity and inhibition of red blood cell invasion by Plasmodium", Scientific RepoRts 6:24368, DOI: https://doi.org/10.1038/srep24368

[15] T.W. Sardjono, Pengaruh Infeksi Toxoplasma pada Hasil Kehamilan Melalui Interferon-gama (IFN- $\gamma$ ), Aktivitas Caspase 3 dan Apoptosis Sel-Sel Plasenta, Library, UNAIR, 2007. 
[16] L.E. Fitri, T.W. Sardjono, Z. Rahmah, B. Siswanto, K, Handono, Y.P. Dachlan, "Low Fetal Weight is Directly Caused by Sequestration of Parasites and Indirectly by IL-17 and IL-10 Imbalance in the Placenta of Pregnant Mice with Malaria", Korean J Parasitol, 53(2) (2015) pp. 189-196. DOI: https://doi.org/10.3347/kjp.2015.53.2.189

[17] J. Bailie, Comprehensive Rodent Service: Breeding Systems, Yale Animal Resources Center, Yale University, 2000.

[18] A. Muthusamy, R.N. Achur, V.P. Bhavanandan, G.G. Fouda, D.W. Taylor, "Plasmodium falciparum Infected Erythrocytes Adhere Both in the Intervillous Space and on the Villous Surface of Human Placenta by Binding to the low-sulfated chondroitin sulfate proteoglycan receptor". Am J Pathol. 164 (2004) 2013-2025. DOI: https://doi.org/10.1016/S0002-9440(10)63761-3.

[19] R. Neres, C.R.F. Marinho, L.A. Goncalves, M.B. Catarino, Penha-Goncalves. "Pregnancy Outcome and Placenta Pathology in Plasmodium berghei ANKA Infected Mice Reproduce the Pathogenesis of Severe Malaria in Pregnant Women". Plos One, 3(2) (2007) e1608. DOI: https://doi.org/10.1371/journal. Pone.0001608.

[20] A.V. Pandey and V.S. Chauhan, Heme Polymerization by Malarial Parasit: A Potensial Target For Antimalarial Drug Development, India: International Centre for Genetic Engineering and Biotechnology, 2000.

[21] S. R. Meshnick, "Artemisinin and the Anti Malarial Endoperoxides, From Herbal Remedy to Targeted Chemotherapy", Microbiology Review, 60, (1996) 301-315.

[22] D.J. Sullivan, G. Ilya, D.G. Russell, and D.E. Goldberg, "On The Molecular Mechanism Of Chloroquine's Antimalarial Action". Medical sciences, 93 (1996) $11865-11870$.

[23] P.J. Rosenthal and S.R. Mesnick, Hemoglobin Catabolism And Iron Utilization By Malaria Parasites, Molecular and Biochemical Parasitology, 1996.

[24] E. Hempelmann and T.J. Egan, "Pigment Biocrystallization in Plasmodium falciparum", Trends in Parasitology, 18 (1) (2002) DOI: https://doi.org/10.1016/S1471-4922(01)02146-8
[25] A. Robert and B. Meunier, "Alkylating Properties Of Antimalarial Artemisinin Derivatives And Synthetic Trioxanes When Activated By Reduced Heme Model", Chem.Eur Journal, 4(7) (2001) 1287-1296.

DOI:

https://doi.org/10.1002/(SICI)1521-

3765(19980710)4:7<1287::AID-

CHEM1287>3.0.CO;2-J

[26] U. Eckstein-Ludwig, R.J. Webb, I.D.A. Van Goethem, J.M. East, A.G. Lee, M. Kimura, P.M. O'Neill, P.G. Bray, S.A. Ward, S. Krishna, "Artemisinins Target The SERCA of Plasmodium falciparum". Nature, 424 (2003) DOI: https://doi.org/10.1038/nature01813.

[27] K.T. Andrews, N. Klatt, Y. Adams, P. Mischnick, \& R. Schwartz-Albiez, "Inhibition of chondroitin-4sulfate-specifc adhesion of Plasmodium falciparuminfected erythrocytes by sulfated polysaccharides". Infect. Immun, 73 (2005) pp. 4288-4294. DOI: https://doi.org/10.1128/IAI.73.7.4288-4294.2005

[28] Y. Adams, C. Freeman, R. Schwartz-Albiez, V. Ferro, C.R. Parish, K. T. Andrews, "Inhibition of Plasmodium falciparum growth in vitro and adhesion to chondroitin-4-sulfate by the heparan sulfatemimetic PI-88 and other sulfated oligosaccharides". Antimicrob. Agents Chemother.2006. 50, pp. 2850-2852. DOI: https://doi.org/ 10.1128/AAC.00313-06.

[29] L. Xiao, C. Yang, P.S. Patterson, V. Udhayakumar, \& A.A. Lal, "Sulfated polyanions inhibit invasion of erythrocytes by plasmodialmerozoites and cytoadherence of endothelial cells to parasitized erythrocytes". Infect. Immun. 1996.64, pp. 13731378 .

[30] A, Najer, A. Najer, D. Wu, A. Bieri, F. Brand, C. G. Palivan, H.P. Beck, and W. Meier, "Nanomimics of host cell membranes block invasion and expose invasive malaria parasites". ACS Nano 2014.8, pp. 12560-12571.

DOI: https://doi.org/10.1021/nn5054206

[31] M.J. Boyle, J.S. Richards, P.R. Gilson, W. Chai. \& J.G. Beeson, "Interactions with heparin-like molecules during erythrocyte invasion by Plasmodium falciparum merozoites", Blood, 115, pp. 4559-4568. DOI: https://doi.org/10.1182/blood2009-09-243725 